\title{
Survey on Prevalence of Stemphylium Blight Disease (Stemphylium vesicarium (Wallr.) E. Simmons) of Onion (Allium cepa L.)in Kashmir Valley
}

\author{
Mudasir Hassan*, Vaseem Yousuf, N.A. Bhat, Z.A. Bhat, \\ M.A. Khan and M.A. Chattoo
}

\begin{abstract}
Division of Plant Pathology, Faculty of Agriculture, Sher-e-Kashmir, University of Agricultural Sciences \& Technology of Kashmir, Wadura, Sopore, India
\end{abstract}

*Corresponding author

\section{A B S T R A C T}

Survey conducted during the year 2016 and 2017 at three stage of crop growth of onion in four districts of the Kashmir valley revealed the prevalence of disease in all onion growing

Keywords

Prevalance,

Disease, Onion, Incidence, Intensity, Kashmir

Article Info

Accepted:

18 September 2018

Available Online:

10 October 2018 areas of the valley during the month of May and June, while during the month of April prevalence of disease was recorded at only few locations, while as rest of the locations were disease free with overall incidence of 1.70, 28.02 and 60.33 and intensity of 0.30 , 5.96 and 36.44 per cent, during the month of April, May and June, respectively. The disease was severe during 2017 with overall mean disease incidence of 1.7328 .27 and 62.74 and intensity of $0.31,6.06$ and 38.12 percent in comparison to 2016 with overall incidence of $1.67,27.77$ and 57.92 and intensity of $0.30,5.85$ and 34.06 percent, during the month of April, May and June, respectively. Perusal of the pooled data of two years revealed that the disease incidence and intensity in surveyed areas varied from 42.90 to 73.48 and 25.31 to 49.36 per cent, respectively with highest incidence and intensity recorded in Anantnag and lowest in Srinagar. Of the 12 locations surveyed, highest disease incidence $(90.59 \%)$ and intensity $(59.86 \%)$ was recorded at Chadoora followed by Bijbhera, Sangam, Ompora, Wadura and Larnoo, respectively. Shalimar, Pattan, Achabal and Danderkah recorded the disease parameters to moderate levels. Least incidence $(27.20 \%)$ and intensity $(16.17 \%)$ was recorded at Noorbagh (Srinagar).

\section{Introduction}

Onion (Allium cepa) is one of the most important and familiar spices crop throughout the world. It is the member of the family Alliaceae. It is also used as popular vegetable in many countries of Asia and very common, favourite spice in India. Onion has manifold uses as spices, vegetables, salad dressing etc.
It is also used as condiments for flavoring a number of food and medicines (Vohra et al., 1974; Hasan, 2007). Onion suffers from many diseases caused by fungi, bacteria, viruses, nematodes and abiotic factors (Meah and Khan, 1987). Among the fungal disease stemphylium blight (Stemphylium vesicarium) is the most serious and devastating disease of onion limiting the quality and quantity of both 
bulb and seed (Daljeet et al., 1992). The disease is characterized by appearance of small yellow to orange streaks which soon developed into elongated, spindle shaped to ovate elongate diffusate spots surrounded by characteristics pinkish margin. It can cause severe damage, especially to the onion seed crop and losses of about $80-85 \%$ on the crop by affecting leaves and seed stalk (Tomaz and Lima, 1988). This disease is widespread particularly in rainy season or high moisture conditions. Thus, survey and surveillance from the basis is useful for any successful plant protection strategy. Successful plant protection depends upon early detection of the disease severity followed by timely adoption and application of preventive measures (Sudarshan Rao, 1975).

However, systematic survey on the distribution and severity in Kashmir valley is lacking. There is need to undertake systemic survey to identify hot spots for these diseases in both south, central and north and Kashmir. Keeping all these aspects in view, the present investigation was undertaken to know the disease severity in major onion growing areas of Kashmir.

\section{Materials and Methods}

The present investigation was conducted in the Division of Plant Pathology, Faculty of Agriculture, Sher-e-Kashmir University of Agricultural Sciences \& Technology of Kashmir, Wadura, Sopore. The materials and methods which were adopted to achieve the set goals are described as follows:

\section{Status of the disease}

To ascertain the status of disease, extensive survey of onion growing areas of four districts viz., Baramulla, Srinagar, Budgam and Anantnag of Kashmir valley was conducted during the first fortnight of April, May and
June of cropping season 2016 and 2017. Three representative villages from each district and three random onion fields were selected from each village. Ten plants along W-pattern transact from each site were observed for recording per cent disease incidence and intensity.

The per cent disease incidence shall be calculated as per the formula given below:

Per cent disease incidence shall be calculated as per the formulla:

Per cent disease incidence $=\frac{\text { Number of diseased leaves }}{\text { Total Number ofleaves examined }} \times 100$

The percent disease intensity was recorded using slightly modified 0-4 scale as adopted by Bisht and Thomas (1992). Five categories were made on the basis of percent leaf area diseased (Plate) as per the following key.

Per cent Disease Intensity (PDI) shall be worked out by using the following formula:

Sum of individual ratings Percent Disease Intensity (PDI) = ------- x 100

No. of leaves examined $x$ Maximum disease score

\section{Results and Discussion}

The experimental finding of the research work is presented under following headings:

\section{Status of the disease}

The disease survey was conducted in four districts of kashmir valley namely, Baramulla, Srinagar, Budgam and Anantnag during two consecutive years i.e. 2016 and 2017. Incidence and intensity was recorded at three stages of survey each year during the first fortnight of April, May and June and the data is presented in Table 1 and 2. 


\section{Disease incidence}

The data reveals (Table 1) that stem phylium blight of onion was prevalent in all the locations surveyed with varying degree of incidence, which was minimum in first but maximum in last (third) stage of survey. Disease incidence in the third stage of survey ranged between 24.43 and 89.51 percent and 29.98 and 94.59 percent during 2016 and 2017 , respectively.

During the year 2016, highest disease incidence of 8.82 per cent at first stage of survey ( $\mathrm{I}^{\mathrm{st}}$ fortnight of April) was recorded at Chadoora, Budgam, followed by Bijbhera $(6.16 \%)$ and minimum of 5.06 per cent was recorded at Sangam, Anantnag while as rest of locations were disease free. During the second stage of survey (Ist fortnight of May), the highest disease incidence of 38.28 per cent was recorded at Chadoora, Budgam, followed by Bijbhera Anantnag, (37.45\%), Sangam Anantnag (35.95\%), Ompora, Budgam (28.68\%), Wadura, Baramulla (30.97\%) and Larnoo, Anantnag (55.09\%), respectively which had increased to $89.51,77.55,76.06$, $69.10,68.27,55.09$ per cent, respectively at third stage of survey.

Other localities, which followed in decreasing order of disease incidence during the second and third stages of survey during 2016 were Shalimar, Pattan, Achabal and Danderkah. Minimum disease incidence of 14.01 and 24.43 per cent at second and third stages, respectively during 2016 was recorded at Noorbagh, Srinagar.

The data further reveals that disease incidence during 2017 varied between different locations in the same way as in 2016. Highest disease incidence of 9.45 per cent at first stage of survey ( $\mathrm{I}^{\text {st }}$ fortnight of April) was recorded at Chadoora, Budgam, followed by Bijbhera $(6.26 \%)$ and minimum of 5.16 per cent was recorded at Sangam, Anantnag while as rest of locations were disease free. During the second stage of survey (Ist fortnight of May), the highest disease incidence of 38.67 per cent was recorded at Chadoora, Budgam, followed by Bijbhera Anantnag, (37.77\%), Sangam Anantnag (36.07\%), Ompora, Budgam (35.89\%), Wadura, Baramulla (31.74\%) and Larnoo, Anantnag (25.72\%), respectively which had increased to $94.59,81.49,79.92$, $70.67,69.90,59.04$ per cent, respectively at third stage of survey. Other localities, which followed in decreasing order of disease incidence during the second and third stages of survey during 2016 were Shalimar, Pattan, Achabal and Danderkah. Minimum disease incidence of 14.64 and 29.98 per cent at second and third stages, respectively during 2017 were recorded at Noorbagh, Srinagar.

The pooled data of 2016-17 revealed that highest disease incidence of 9.13 per cent at first stage of survey was recorded at Chadoora, Budgam, followed by Bijbhera $(6.21 \%)$ and minimum at Sangam $(5.11 \%)$ of district Anantnag while as rest of locations were disease free during first stage of survey.

During the second stage of survey (Ist fortnight of May), the highest disease incidence of 38.47 per cent was recorded at Chadoora, Budgam, followed by Bijbhera (37.77\%) Anantnag, (36.07\%), Sangam, Anantnag, (35.87\%) Ompora, Budgam, Wadura (31.35\%), Baramulla, Larnoo $(29.22 \%)$, Anantnag which had increased to $90.59,81.49,79.92,69.88,69.08,59.04$ per cent, respectively at third stage of survey. Other localities, which followed in decreasing order of disease incidence during the second and third stages of survey during 2016 were Shalimar, Pattan, Achabal and Danderkah. Minimum disease incidence of 14.33 and 27.21 per cent at second and third stages, respectively during 2016-17 were recorded at Noorbagh, Srinagar. 
Table.1 Incidence of Stemphylium blight of onion (S. vesicarium) at various locations of Kashmir during 2016-2017

\begin{tabular}{|c|c|c|c|c|c|c|c|c|c|c|}
\hline District & \multirow{3}{*}{ Location } & \multicolumn{9}{|c|}{ Disease incidence (\%) } \\
\hline \multirow{6}{*}{ Anantnag } & & \multicolumn{3}{|c|}{2016} & \multicolumn{3}{|c|}{2017} & \multicolumn{3}{|c|}{ POOLED } \\
\hline & & April* & May & June & April & May & June & April & May & June \\
\hline & Sangam & $5.06 * *$ & 35.95 & 76.06 & 5.16 & 36.19 & 83.79 & 5.11 & 36.07 & 79.92 \\
\hline & Bijbhera & 6.16 & 37.45 & 77.55 & 6.26 & 38.09 & 85.44 & 6.21 & 37.77 & 81.49 \\
\hline & Larnoo & 0.00 & 28.68 & 55.09 & 0.00 & 29.76 & 62.99 & 0.00 & 29.22 & 59.04 \\
\hline & Mean & 3.74 & 34.02 & 69.56 & 3.80 & 34.68 & 77.40 & 3.77 & 34.35 & 73.48 \\
\hline \multirow{4}{*}{ Srinagar } & Shalimar & 0.00 & 25.13 & 55.35 & 0.00 & 25.71 & 62.69 & 0.00 & 25.41 & 59.02 \\
\hline & Danderkah & 0.00 & 16.98 & 38.82 & 0.00 & 17.06 & 46.14 & 0.00 & 17.02 & 42.48 \\
\hline & Noorbagh & 0.00 & 14.03 & 24.43 & 0.00 & 14.04 & 29.08 & 0.00 & 14.32 & 27.20 \\
\hline & Mean & 0.00 & 18.70 & 39.53 & 0.00 & 19.13 & 46.27 & 0.00 & 18.91 & 42.90 \\
\hline \multirow{4}{*}{ Budgam } & Chadoora & 8.82 & 38.28 & 89.51 & 9.45 & 38.67 & 94.59 & 9.13 & 38.47 & 90.59 \\
\hline & Magam & 0.00 & 26.38 & 45.09 & 0.00 & 27.21 & 47.03 & 0.00 & 26.79 & 46.06 \\
\hline & Ompora & 0.00 & 35.85 & 69.10 & 0.00 & 35.89 & 70.67 & 0.00 & 35.87 & 69.88 \\
\hline & Mean & 2.94 & 33.50 & 67.90 & 3.15 & 33.92 & 70.76 & 3.04 & 33.71 & 69.33 \\
\hline \multirow{5}{*}{ Baramulla } & Wadura & 0.00 & 30.97 & 68.27 & 0.00 & 31.74 & 69.90 & 0.00 & 31.35 & 69.08 \\
\hline & Pattan & 0.00 & 22.48 & 49.29 & 0.00 & 22.68 & 48.99 & 0.00 & 22.58 & 50.03 \\
\hline & Achabal & 0.00 & 21.24 & 46.52 & 0.00 & 21.72 & 56.55 & 0.00 & 21.48 & 47.75 \\
\hline & Mean & 0.00 & 24.89 & 54.69 & 0.00 & 25.38 & 62.74 & 0.00 & 25.13 & 55.62 \\
\hline & Overall mean & 1.67 & 27.77 & 57.92 & 1.73 & 28.27 & 62.74 & 1.70 & 28.02 & 60.33 \\
\hline \multicolumn{11}{|l|}{$\mathrm{CD}_{(\mathrm{P} \leq 0.05)}$} \\
\hline District & & 0.37 & 0.42 & 1.85 & 0.22 & 0.39 & 1.41 & 0.01 & 0.31 & 1.23 \\
\hline Location & & 0.32 & 0.37 & 1.60 & 0.19 & 0.34 & 1.22 & 0.02 & 0.27 & 1.06 \\
\hline
\end{tabular}

* Survey conducted during Ist fortnight in the month April, May and June

** Data presented is average of the observations recorded in three fields at each location. 
Table.2 Intensity of Stemphylium blight of onion (S. vesicarium) at various locations of Kashmir during 2016-2017

\begin{tabular}{|c|c|c|c|c|c|c|c|c|c|c|}
\hline District & Location & \multicolumn{9}{|c|}{ Disease intensity (\%) } \\
\hline \multirow{4}{*}{ Anantnag } & & \multicolumn{3}{|c|}{2016} & \multicolumn{3}{|c|}{2017} & \multicolumn{3}{|c|}{ POOLED } \\
\hline & Sangam & $1.10 * *$ & 7.85 & 54.18 & 1.11 & 7.92 & 59.12 & 1.10 & 7.88 & 56.65 \\
\hline & Bijbhera & 1.16 & 8.40 & 55.50 & 1.18 & 8.50 & 59.40 & 1.17 & 8.45 & 57.45 \\
\hline & Larnoo & 0.00 & 5.58 & 33.54 & 0.00 & 6.07 & 34.44 & 0.00 & 5.82 & 33.99 \\
\hline \multirow{4}{*}{ Srinagar } & Shalimar & 0.00 & 5.35 & 32.57 & 0.00 & 5.42 & 33.18 & 0.00 & 5.38 & 32.87 \\
\hline & Danderkah & 0.00 & 3.42 & 16.58 & 0.00 & 3.73 & 28.84 & 0.00 & 3.57 & 26.91 \\
\hline & Noorbagh & 0.00 & 2.82 & 13.60 & 0.00 & 2.85 & 18.74 & 0.00 & 2.83 & 16.17 \\
\hline & Mean & 0.00 & 3.86 & 20.91 & 0.00 & 4.00 & 26.92 & 0.00 & 3.92 & 25.31 \\
\hline Budgam & Chadoora & 1.36 & 8.50 & 57.40 & 1.44 & 8.52 & 62.33 & 1.40 & 8.51 & 59.86 \\
\hline \multirow{5}{*}{ Baramulla } & Wadura & 0.00 & 6.75 & 34.47 & 0.00 & 6.84 & 39.37 & 0.00 & 6.79 & 36.92 \\
\hline & Pattan & 0.00 & 4.63 & 25.48 & 0.00 & 4.71 & 30.18 & 0.00 & 4.67 & 27.83 \\
\hline & Achabal & 0.00 & 4.58 & 24.66 & 0.00 & 4.63 & 21.24 & 0.00 & 4.60 & 22.95 \\
\hline & Mean & 0.00 & 5.32 & 28.20 & 0.00 & 5.39 & 30.26 & 0.00 & 5.35 & 29.23 \\
\hline & Overall mean & 0.30 & 5.85 & 34.06 & 0.31 & 6.06 & 38.12 & 0.30 & 5.95 & 36.44 \\
\hline \multicolumn{11}{|l|}{$\mathrm{CD}_{(\mathrm{P} \leq 0.05)}$} \\
\hline District & & 0.01 & 0.22 & 0.92 & 0.05 & 0.24 & 0.89 & 0.03 & 0.15 & 0.56 \\
\hline Location & & 0.02 & 0.19 & 0.80 & 0.04 & 0.20 & 0.77 & 0.02 & 0.13 & 0.48 \\
\hline
\end{tabular}




\section{Status of the disease}

\begin{tabular}{|c|c|l|}
\hline Category & Numerical Value & \multicolumn{1}{|c|}{ Criteria } \\
\hline I. & 0 & No infection \\
\hline II. & 01 & $1-10 \%$ onion leaves covered with disease \\
\hline III. & 02 & $10.1-25 \%$ onion leaves covered with disease \\
\hline IV. & 03 & \begin{tabular}{l}
$25.1-50 \%$ onion leaves covered with disease \\
\hline V.
\end{tabular} \\
\hline
\end{tabular}

\section{Disease intensity}

The data presented in Table 2 reveals that intensity of stemphylium blight of onion varied between locations surveyed and was minimum at each locality at the time of first survey but maximum at third stage of survey ranged between and per cent, and per cent during 2016 and 2017, respectively. During the year 2016, highest disease intensity of 1.36 per cent at first stage of survey (Ist fortnight of April) was recorded at Chadoora, Budgam, followed by Bijbhera (1.16\%) and minimum of 1.10 per cent was recorded at Sangam, Anantnag while as rest of locations were disease free. During the second stage of survey (Ist fortnight of May), the highest disease intensity of 8.50 per cent was recorded at Chadoora, Budgam, followed by Bijbhera Anantnag, (8.40\%), Sangam, Anantnag (7.85\%), Ompora, Budgam (7.70\%), Wadura, Baramulla (6.75\%) and Larnoo, Anantnag (5.58\%), respectively which had increased to $57.40,55.50,54.18,36.42,34.47$ and 33.54 per cent, respectively at third stage of survey.

Other localities, which followed in decreasing order of disease incidence during the second and third stages of survey during 2016 were Shalimar, Pattan, Achabal, and Danderkah. Minimum disease incidence of 2.82 and 13.60 per cent at second and third stages, respectively during 2016 were recorded at Noorbagh, Srinagar. During the year 2017, highest disease intensity of 1.44 per cent at first stage of survey ( ${ }^{\text {st }}$ fortnight of April) was recorded at Chadoora, Budgam, followed by Bijbhera
(1.18\%) and minimum of 1.11 per cent was recorded at Sangam, Anantnag while as rest of locations were disease free. During the second stage of survey ( $\mathrm{I}^{\mathrm{st}}$ fortnight of May), the highest disease intensity of 8.52 per cent was recorded at Chadoora, Budgam, followed by Bijbhera Anantnag, (8.50\%), Sangam, Anantnag (7.92\%), Ompora, Budgam (7.73\%), Wadura, Baramulla (6.84\%) and Larnoo, Anantnag (6.07\%), respectively which had increased to $62.33,59.40,59.12,41.29,39.37$ and 34.44 per cent, respectively at third stage of survey.

Other localities, which followed in decreasing order of disease incidence during the second and third stages of survey during 2016 were Shalimar, Pattan, Achabal, and Danderkah. Minimum disease incidence of 2.85 and 18.74 per cent at second and third stages, respectively during 2017 were recorded at Noorbagh, Srinagar.

The pooled data of 2016-17 revealed that highest disease intensity of 1.40 per cent at first stage of survey was recorded at Chadoora, Budgam, followed by Bijbhera (1.17\%) and minimum at Sangam (1.10\%) of district Anantnag while as rest of locations were disease free during first stage of survey. During the second stage of survey (Ist fortnight of May), the highest disease incidence of 8.51 per cent was recorded at Chadoora, Budgam, followed by Bijbhera Anantnag, (8.45\%), Sangam, Anantnag (7.88\%), Ompora, Budgam, (7.71\%), Wadura, Baramulla (6.79\%) and Larnoo Anantnag (5.82\%), respectively which 
had increased to $59.87,57.45,56.65,38.85$, 36.92 and 33.99 per cent, respectively at third stage of survey. Other localities, which followed in decreasing order of disease incidence during the second and third stages of survey during 2016 were Shalimar, Pattan, Achabal, Larnoo and Danderkah. Minimum disease incidence of 2.83 and 16.17 per cent at second and third stages, respectively during 2016-17 were recorded at Noorbagh, Srinagar.

Higher disease incidence and intensity in various districts and sites could be attributed to higher plant density, besides non disposal of diseased leaves, which serve as a source for buildup of primary inoculum. Overall, variation in disease severity may be because of the variation in various factors like, altitude, climate and management practices. The variations in incidence and severity of stemphylium blight of onion in various locations have previously been reported by (Tesfaendrias, 2012; Gupta et al., 1994). Koppad et al., 2017 reported that stemphylium blight severity ranged from 21.24 to 54.35 per cent in carried out from onion growing districts viz., Dharwad, Gadag, Haveri, Uttar Kannada and Belagavi of Karnataka during kharif 201415 .

\section{References}

Bisht, I. S. and Thomas, T. A.1992. Field screening of garlic germplasm against purple blotch and stemphylium blight. Indian Phytopathol. 45: 244.

Daljeet, S., Dhiman, J. S., Sidhu, A. S. and Hari Singh. 1992. Current status of onions in India. Strategies for distance resistance breeding for sustained production. Onion
News letters for the Tropics4: 43-44.

Gupta, R. P., Srivastava, K. J., Pandey, U. B. and Midmore, D. J. 1994. Diseases and insect pests of onion in India. International Symposium on Alliums for the Tropics. Acta Horti.; 358: 265-269.

Hassan, M. H. A. and Hussein, M. A. M. 2007. New Disease Report. Plant Pathology Department, Faculty of Agriculture, Assiut University, Egypt.

Meah, B. and Khan, A. A. 1987. Checklist of vegetables and fruit diseases in Bangladesh. Department of Plant Pathology, Bangladesh Agriculture University Mymensingh, pp. 22.

Shilpa R. Koppad, S. R., Babaleshwar, S.B., Dharmatti, P. R and Kulkarni, S. 2017. Survey on prevalence and symptomatology of major diseases of onion (Allium cepa L.) in northern parts of Karnataka, India. Int.J.Curr. Microbiol.App.Sci 6(9): 2603-2607

Sudarshan Rao, A.N., 1975. Survey, surveillance and forecast in plant protection. Kissan World 2: 43-44.

Tesfaendrias, M. 2012. Update on stemphylium leaf blight of onions in Ontario. University of Guelph Muck Crop Research Station.

Tomaz. I. L. And Lima, A. 1986. An important disease of onion caused by (Stemphylium vesicarium (Wallr.) E. Simmons) in Portugal. Publicacao Laboratorio de Patologia vegetal Verissimo de Almeida No.48. Lab patologiavegetaleverissimo de Almedia, Lisbon Portugal. pp.4.

Vohra, S. B., Rizman, M. and Khan, J. A. 1974. Medicinal uses of common Indian vegetables. Planta Medica23: 381- 393.

\section{How to cite this article:}

Mudasir Hassan, Vaseem Yousuf, N.A. Bhat, Z.A. Bhat, M. A. Khan and Chattoo, M.A. 2018. Survey on Prevalence of Stemphylium Blight Disease (Stemphylium vesicarium (Wallr.) E. Simmons) of Onion (Allium cepa L.) in Kashmir Valley. Int.J.Curr.Microbiol.App.Sci. 7(10): 23252331. doi: https://doi.org/10.20546/ijcmas.2018.710.269 